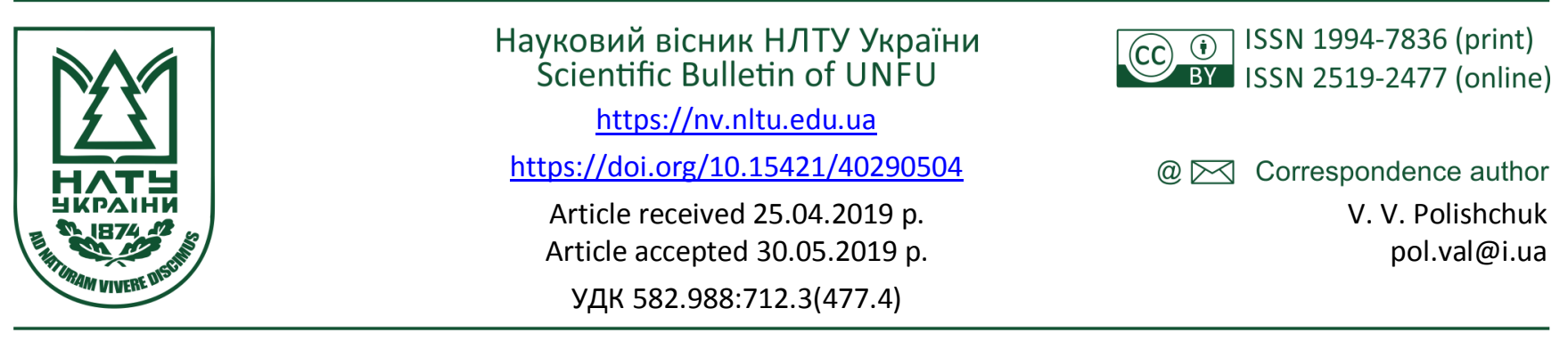

В. В. Полішук, С. Я. Турчина, М. Ю. Осіпов

Уманський національний університет садівництва, м. Умань, Україна

\title{
ПІДБІР СТЕРИЛІЗАТОРА ДЛЯ ВВЕДЕННЯ IN VITRО ДОНОРНОГО МАТЕРІАЛУ ДОСЛІДЖУВАНИХ СОРТІВ CALLISTEPHUS CHINENSIS (L.) NESS. З МЕТОЮ ПОДАЛЬШОГО ВИКОРИСТАННЯ В ОЗЕЛЕНЕННІ
}

\begin{abstract}
За результатами аналізу літературних джерел з'ясовано, що всередині експлантів і в подальшому розвитку з них рослинрегенерантів може проявлятись інфекція, яка була як на поверхні, так і всередині рослини. При цьому істотно знижується частота поділу соматичних чи ембріональних клітин та інші показники росту. Водночас деякі мікроорганізми у певних стадіях розмноження можуть залишатися неактивними впродовж декількох пересадок культури і тільки потім починають розмножуватись. Мета нашої роботи - отримати стерильний неінфікований рослинний матеріал у процесі введення в культуру та в період культивування рослин, провести поверхневу стерилізацію вихідного рослинного матеріалу (насіння) Callistephus chinensis (L.) Nees. залежно від складу живильного середовища. Стерилізацію рослинного матеріалу виконано 5-15 \% розчином хлораміну, і 0,01-0,1 \% розчином сулеми. У ролі стерилізаторів обрано хлорамін, гіпохлорид натрію та септодор-форте 3 різною концентрацією робочого розчину. Кількість введених генотипів становила 100 насінин для всіх стерилізаторів. Визначено, що найефективнішим стерилізатором експлантів рослин калістефусу китайського є $0,5 \%$ розчин гіпохлориду натрію при експозиції стерилізації 15 хв - 98 \% стерильного матеріалу.
\end{abstract}

Ключові слова: живильне середовище; вихідний матеріал; калістефус китайський; сорти; інтродукція; in vitro; господарсько-цінні ознаки; генотип; рослинний матеріал.

Вступ. Квіткові рослини, у яких період росту і розвитку від сівби насіння до збирання триває однин вегетаційний період, віднесено до однорічних. До цих же рослин відносять також і квіткові рослини, які за своїми біологічними особливостями є багаторічниками, однак в різних умовах культивування онтогенез відбувається за один рік (Iaremenko \& Lazitckaia, 1968).

Рід Callistephus chinensis (L.) Ness. походить 3 Далекого Сходу Росії, північних і північно-східних районів Китаю, а також Монголії і Японії. Систематика роду Callistephus chinensis (L.) Ness. змінювалася впродовж тривалого періоду культивування. Там досі айстра збереглася у дикому стані, вона росте переважно на скелях і глиняно-кам'янистих грунтах південних гірських схилів у зоні широколистяних лісів (Nechansky \& Jirasek, 1967).

У літературних джерелах з ботаніки цей вид рослин описано під різними синонімами, а саме Aster hortensis L., Callistemma hortense Cass., Callistephus hortensis Cass., Diplopappus sinensis Less. (Aleksieieva, 1999). Вперше цей вид описав Карл Лінней, який на початковому етапі було віднесено до роду Aster L. У 1826 p. Н. Кассіні виокремив його у вид Callistemma Cass., який пізніше перейменували в Callistephus. Сучасну назву виду - Callistephus chinensis - дав айстрі однорічній Неес (Ness) (Volkova, 1983). Відповідно до сучасних наукових уявлень рід Callistephus Cass. належить до порядку Asterales Link, родини Asteraceae Bercht. et J Presl (Bailey, 1950).

Вперше в Європу вид C. Chinensis інтродукував 3 Китаю у 1728 p. (Angiosperm Phylogeny Group III, 2009) паризький місіонер П'єр Інкервіль, де і було розпочато перші селекційні роботи. Французькі селекціонери створили одну 3 найкращих садових груп- Рів'єра i культивари сортотипу Дюшес. Вони відрізняються великими, потовщеними, густомахровими суцвіттями різного кольору. Також у Франції було створено низку культиваторів Фламір з яскравим різнокольоровим забарвленням і серію сортотипів Міледі заввишки 2030 см, які широко використовуються в озелененні (Shevel \& Alekseeva, 2015).

Айстра належить до родини складноцвіті (айстрові) (Asteraceae). Ботаніки назвали іiі калістефус китайський (Callistephus chinensis), проте в усьому світі цю квітку називають айстра китайська (Callistephus chinensis (L.) Ness.), або айстра однорічна. Це однорічна рослина 3 наведеної вище родини. У перекладі з грецької її назва означає "зірка". Древні вважали, що айстри з'являються

\section{Інформація про авторів:}

Поліщук Валентин Васильович, д-р с.-г. наук, професор, кафедра садово-паркового господарства. Email: роl.val@i.uа Турчина Сніжана Ярославівна, аспірант, кафедра садово-паркового господарства. Email: snezhana.turchina@ukr.net Осіпов Михайло Юрійович, канд. с.-г. наук, доцент, кафедра садово-паркового господарства. Email: m3dsad@gmail.com Цитування за ДСту: Поліщук В. В., Турчина С. Я., Осіпов М. Ю. Підбір стерилізатора для введення in vitro донорного матеріалу досліджуваних сортів Callistephus Chinensis (L.) Ness. з метою подальшого використання в озелененні. Науковий вісник Нлту України. 2019, т. 29, № 5. С. 22-26.

Citation APA: Polishchuk, V. V., Turchina, S. Ya., \& Osipov, M. Yu. (2019). Selection of sterilizer for in vitro introduction of donor material of research Callistephus Chinensis (L.) Ness. varieties for its further use in greening. Scientific Bulletin of UNFU, 29(5), 22-26. https://doi.org/10.15421/40290504 
iз зоряного пилу, який впав 3 неба. На сьогодні ця чудова рослина по праву є однією з найпопулярніших осінніх квіток, найулюбленішою садовою культурою в городян на присадибних ділянках. Цінується за щедре осінне цвітіння, різноманіття забарвлень і форм суцвіть, які через те, що їх центральна частина складається із жовтих трубчастих квіток, по краях оточених довгими язичковими, дійсно нагадують вінок (Kozhevnikov, 2000; Aleksandrova \& Krestnikova, 1991; Petrenko, 2001).

Для створення квіткових композицій у садово-парковому будівництві використовують досить великий асортимент однорічних квіткових рослин, що мають високі декоративні властивості. Серед однорічників вирізняється айстра китайська. Вона не вибаглива до умов вирощування та має багато різноманітних сортів, адаптованих до різних грунтово-кліматичних умов зростання (Surhan \& Melnyk, 2012).

Зі створенням різних типів облаштування, серед яких найвідоміші $з$ використанням айстри однорічної, бордюри, клумби, солітери, групи, міксбордери, масиви, модульні квітники тощо. Багато сортів айстр використовують для посадок на рабатках та айстраріях (Shhelokova, Simonova \& Belova, 1967).

У сучасних ринкових умовах перед селекціонерами постало завдання створити конкурентоспроможні сорти Callistephus chinensis (L.) Ness. 3 основними господарсько-цінними ознаками. 3 цією метою в практику селекційної роботи впроваджується гетерозисна селекція $з$ використанням добору за комбінаційною здатністю, мікроклональне розмноження та ін. Окрім цього, для створення нових сортів і гібридів айстри однорічної необхідною умовою $є$ застосування сучасних методів селекції, що передбачають явища добору і гетерозису. Висока продуктивність та декоративність сортів і гібридів забезпечується не тільки завдяки ефекту гібридизації, а також $є$ результатом наявності комплексу інших господарських ознак, за якими селекціонер проводить добір (Shevel \& Rudnyk-Ivashchenko, 2016).
На особливу увагу заслуговує створення і покращення сортів та гібридів айстри однорічної за допомогою підтримувальної селекції, що забезпечить підвищення декоративності і насіннєвої продуктивності (Воreiko, 1989; Antoniuk \& Iashhenko, 2005). До завдань селекції належить отримання сортів, здатних давати повноцінні сходи при комплексі несприятливих погодних і грунтових умов, добре адаптованих до різних агрокліматичних умов вирощування (Turchyna et al., 2017).

Істотне збільшення врожайності сільськогосподарських культур за останні десятиліття призвело до виникнення економічних і екологічних проблем, пов'язаних із забрудненням навколишнього середовища, виснаженням енергетичних ресурсів, зростанням витрат на одиницю продукції. Окрім цього, додатковий прогрес у поліпшенні якості найважливіших сільськогосподарських культур із застосуванням класичних методів генетики і селекції здебільшого досяг своєї межі. Пошук нових підходів, які дали б змогу не тільки підвищити врожаї і поліпшити якість основних сільськогосподарських культур, а й були економічно вигідніші у виробництві і не завдавали шкоди навколишньому середовищу, зумовив до використання в практиці національного господарства методів сучасних біотехнологій (Melnychuk, Novak \& Kunakh, 2003).

Отже, певний дефіцит і зауваження щодо широкого впровадження досягнень вітчизняного та зарубіжного досвіду зі створення нових генотипів Callistephus chinensis (L.) дасть змогу збагатити сортимент в Україні, збільшити кількість сортів, різноманітних за формою, розміром, кольором, тривалістю цвітіння, придатних для вирощування у квітниках та створення букетів. Це дає підстави стверджувати про актуальність досліджень у цьому напрямку.

Методика проведення дослідження. У наших дослідженнях використано 20 сортів рослин калістефусу китайського з різними важливими ознаками, походженням та напрямом використання. Характеристику сортів наведено у табл. 1.

Таб̆л. 1. Характеристика сортів

\begin{tabular}{|c|c|c|c|c|c|}
\hline № 3/ח & Назва сорту & Походження & Сортотип & $\begin{array}{c}\text { Продуктивність, } \\
\text { Гүкуща }\end{array}$ & $\begin{array}{c}\text { Напрям } \\
\text { використання }\end{array}$ \\
\hline 1 & Кінг Сайз & Німеччина & \multirow{6}{*}{ Півонієподібна } & $3,0-4,0$ & універсал. \\
\hline 2 & Анастасія (куп.) & IC HAAH & & $3,0-3,5$ & універсал. \\
\hline 3 & Анастасія (Соф.) & IC HAAH & & $3,0-3,5$ & універсал. \\
\hline 4 & СалмонТурм & Німеччина & & $2,5-3,0$ & універсал. \\
\hline 5 & Оксана & IC HAAH & & $2,5-3,0$ & універсал. \\
\hline 6 & Одарка & IC HAAH & & $3,5-4,0$ & на зрізку \\
\hline 7 & Хільда & Німеччина & \multirow{3}{*}{ Принцеса } & $4,5-5,0$ & на зрізку \\
\hline 8 & Принцеса (красная) & IC HAAH & & до 6 & на зрізку \\
\hline 9 & Александра & Німеччина & & $4,5-5,0$ & на зрізку \\
\hline 10 & Малиновий шар & Росія & \multirow{3}{*}{ Помпонні } & до 6 & універсал. \\
\hline 11 & Зімняявішня & Західна Європа & & $2,0-2,5$ & універсал. \\
\hline 12 & Голубая луна & Західна Європа & & $\frac{2, v-2,5}{2,0-2,5}$ & на зрізку \\
\hline 13 & Софія & IC HAAH & Художня & $3,0-3,5$ & універсал. \\
\hline 14 & Лебедине озеро & IC HAAH & Художня & 2,0 & на зрізку \\
\hline 15 & Есмеральда & Німеччина & \multirow{2}{*}{ Куляста } & $3,0-3,5$ & на зрізку \\
\hline 16 & Оксамит & IC HAAH & & $2,0-2,5$ & універсал. \\
\hline 17 & Сєдая Дама (синя) & Росія & Дюшес & $2,5-3,0$ & на зрізку \\
\hline 18 & Веснянка & IC HAAH & Трояндоподібна & 4,0 & універсал. \\
\hline 19 & Сніжана & IC HAAH & Лаплата & 3,0 & на зрізку \\
\hline 20 & Янтарна & IC HAAH & Американська кущова & 3,5 & на зрізку \\
\hline
\end{tabular}

Дослідження проведено в навчально-науково-виробничій лабораторії біотехнології Уманського національного університету садівництва. Для досліджень вико- ристовували генотипи калістефусу китайського (Callistephus chinensis (L.) Nees.) 3 високими господарськоцінними ознаками, закономірності прояву їх регенера- 
ційної здатності в умовах in vitro та in vivo для створення садивного матеріалу.

Унаслідок проведених досліджень було виділено шість генотипів калістефусу китайського за важливими господарсько-цінними ознаками, які надалі використали для введення in vitro.

Під час організації робіт з культури тканин використовували приміщення, в яких проводять такі операції:

- приготування, стерилізація та зберігання живильних середовищ;

• виконання робіт із чистими культурами (операційна);

- культивування експлантатів (термостатно-світлова кімната);

- стерилізація живильних середовищ, посуду, інструментів, спецодягу (автоклавна);

- підсобні приміщення.

У лабораторних кімнатах встановлено автоклави, дистилятори, аналітичні та лабораторні ваги, рН-метри, лабораторні столи, шафи для посуду, ламінар-бокси для роботи з чистими культурами, культиваційні стелажі та інше обладнання, необхідне для виконання робіт 3 культури тканин.

Стерилізація посуду, інструментів, приміщень. Посуд, інструменти стерилізували в сушильних шафах сухим гарячим повітрям дві години за температури $+140{ }^{\circ} \mathrm{C}$. Під час роботи в ламінар-боксі інструменти утримували в посудині з $96 \%$ етиловим спиртом і після кожної маніпуляції їх обпалювали в полум'ї спиртівки. Вату, марлю, халати, пробки, воду, живильні середовища стерилізували в автоклаві. Матеріали стерилізували в автоклаві за тиску в дві атмосфери (температура $+133{ }^{\circ} \mathrm{C}$ ) упродовж 30 хв. Для стерилізації приміщень використовували ртутно-кварцеві та бактерицидні лампи. Світильники з лампами розміщені під стелею в різних місцях боксу і в тамбурі.

Для знищення спорових форм бактерій операційну кімнату періодично прибирали 3 використанням розчинів мийних та антисептичних засобів. Бактерицидні лампи в операційній кімнаті вмикали на 1-2 год напередодні виконання запланованих робіт. Стерилізація живильних середовищ та рослинного матеріалу. Живильні середовища стерилізували за тиску 0,9-1,0 атмосфери (температура $+115-120^{\circ} \mathrm{C}$ ) упродовж $15 \mathrm{xв}$, за об'ємів середовища 50 мл. Для поверхневої стерилізації рослинного матеріалу, із якого вилучали верхівкові меристеми, використовували розчин гіпохлорид кальцію та розчин сулеми.

Результати дослідження. Після відбору експланту потрібно звернути увагу на дезінфекційну обробку рослинного матеріалу (Shhelokova, Simonova \& Belova, 1967). Дезінфекція донорного матеріалу потрібна для видалення мікроорганізмів, які знаходяться на поверхні рослини, за наявності якого проходить негативний вплив на ріст і розвиток експлантів, а потім і загалом на рослину. Інфікованість рослини грибами і бактеріями, якщо вони не виявлені раніше, значно знижує біологічні процеси росту і розвитку всієї рослини. Вегетативні експланти здорових культур проходять стерилізацію різними препаратами і в різний період часу (Guliaev \& Guzhov, 1972).

Аналіз літературних джерел свідчить про те, що всередині експлантів і в подальшому розвитку з них рослин-регенерантів може проявлятись інфекція, яка знаходилась як на поверхні, так і всередині рослини. При цьому істотно знижується частота поділу соматичних чи ембріональних клітин та інші показники росту. При цьому, деякі мікроорганізми у певних стадіях розмноження можуть залишатися неактивними протягом декількох пересадок культури і тільки потім починають розмножуватись (Boroevich \& Fedorov, 1984).

Мета роботи - отримати стерильний неінфікований рослинний матеріал у процесі введення в культуру та в період культивування рослин, здійснити поверхневу стерилізацію вихідного рослинного матеріалу (насіння) Callistephus chinensis (L.) Nees. залежно від складу живильного середовища. При цьому на перших етапах стерилізації провели такі дії: стерилізація посуду, інструментів, приміщень. Посуд, інструменти стерилізували в сушильних шафах сухим гарячим повітрям дві години за температури $+140{ }^{\circ} \mathrm{C}$. Під час роботи в ламінар-боксі інструменти утримували в посудині з $96 \%$ етиловим спиртом і після кожної маніпуляції їх обпалювали в полум'ї спиртівки. Вату, марлю, халати, пробки, воду, живильні середовища стерилізували в автоклаві. Матеріали стерилізували в автоклаві за тиску в дві атмосфери (температура $+133^{\circ} \mathrm{C}$ ) упродовж 30 хв.

Для стерилізації приміщень використовували ртутно-кварцеві та бактерицидні лампи. Світильники $з$ лампами розміщені під стелею в різних місцях боксу і в тамбурі. Для знищення спорових форм бактерій операційну кімнату періодично прибирали з використанням розчинів мийних та антисептичних засобів. Бактерицидні лампи в операційній кімнаті вмикали на 1-2 год напередодні проведення запланованих робіт.

Перед стерилізацією експлантів промивали рослинний матеріал стерильною водою 15-20 хв, щоб з поверхні насінини змити грибково-бактеріальні інфекції. Стерилізований матеріал у ламінар-боксі вводили на краще за рекогносцирувальними дослідженнями безгормональне середовище за прописом Мурасіге і Скуга (MS) (Gamborg \& Eveleigh, 1968).

Стерилізацію рослинного матеріалу проводили 5$15 \%$ розчином хлораміну, і $0,01-0,1 \%$ розчином сулеми. У ролі стерилізаторів обрали хлорамін, гіпохлорид натрію та септодор-форте з різною концентрацією робочого розчину. Кількість введених генотипів становила 100 насінин для всіх стерилізаторів. Решту маніпуляцій з рослинним матеріалом виконували за загальновживаними методиками (Butenko, 1964, 1999).

За результатами проведених досліджень доведено, що в разі стерилізації від однієї хвилини до п'яти вихід стерильних живців не перевищував нуля. Зі збільшенням експозиції від п'ятої хвилини до десяти майже на одному рівні були стерилізатори хлорамін 0,05 \% і септодор-форте, вихід стерильних життєздатних експлантів становив близько $15 \%$, а стерилізація рослинного матеріалу хлораміном давала найменший вихід живців - від 15 до $19 \%$ (табл. 2).

Найефективнішою стерилізаційною речовиною для введення експлантів в ізольовану культуру визначено 0,15 \% водний розчин гіпохлориду натрію за експозиції 15 хв. Вихід стерильних життєздатних рослин-регенерантів, з яких потім розвивались майбутні генотипи, у цьому варіанті досліду в середньому становив $98 \%$ (рис. 1,a). Однак, у разі подальшого підвищення експозиції стерилізації вихід стерильних експлантів досягав $100 \%$, при цьому вони були повністю нежиттєздатними (рис. 1,б). 
Табл. 2. Ефективність стерилізації рослинного матеріалу залежно від типу стерилізатора, концентрації і експозиції, (2017-2018 pp.)

\begin{tabular}{|c|c|c|c|c|}
\hline $\begin{array}{l}\text { Назва сте- } \\
\text { рилізатора }\end{array}$ & $\begin{array}{c}\text { Концен- } \\
\text { тра- } \\
\text { ція, \% }\end{array}$ & $\begin{array}{c}\text { Експозиція } \\
\text { стериліза- } \\
\text { ції, хв }\end{array}$ & $\begin{array}{l}\text { Вихід неінфі- } \\
\text { кованих } \\
\text { життєздатних } \\
\text { експлантів, \% }\end{array}$ & $\begin{array}{c}\text { Кількість } \\
\text { експлантів } \\
3 \text { некро- } \\
\text { зом, \% }\end{array}$ \\
\hline \multirow{9}{*}{ Хлорамін } & \multirow{3}{*}{5} & 10 & 15 & - \\
\hline & & 15 & 19 & 1 \\
\hline & & 20 & 21 & 6 \\
\hline & \multirow{3}{*}{10} & 10 & 19 & 1 \\
\hline & & 15 & 23 & 1 \\
\hline & & 20 & 25 & 8 \\
\hline & \multirow{3}{*}{15} & 10 & 54 & 2 \\
\hline & & 15 & 83 & 8 \\
\hline & & 20 & 41 & 16 \\
\hline \multirow{9}{*}{$\begin{array}{c}\text { Гіпохло- } \\
\text { рид натрію }\end{array}$} & \multirow{3}{*}{5} & 10 & 17 & - \\
\hline & & 15 & 24 & - \\
\hline & & 20 & 18 & 7 \\
\hline & \multirow{3}{*}{10} & 10 & 63 & - \\
\hline & & 15 & 69 & 6 \\
\hline & & 20 & 9 & 11 \\
\hline & \multirow{3}{*}{15} & 10 & 59 & - \\
\hline & & 15 & 98 & - \\
\hline & & 20 & 87 & - \\
\hline \multirow{9}{*}{$\begin{array}{c}\text { Септодор- } \\
\text { форте }\end{array}$} & \multirow{3}{*}{1,25} & 10 & 55 & - \\
\hline & & 15 & 83 & 6 \\
\hline & & 20 & 90 & 10 \\
\hline & \multirow{3}{*}{2,5} & 10 & 43 & 5 \\
\hline & & 15 & 81 & 10 \\
\hline & & 20 & 84 & 8 \\
\hline & \multirow{3}{*}{5} & 10 & 15 & 68 \\
\hline & & 15 & 19 & 82 \\
\hline & & 20 & 26 & 93 \\
\hline $\mathrm{HIP}_{0,5}$ & & & 6,0 & \\
\hline
\end{tabular}

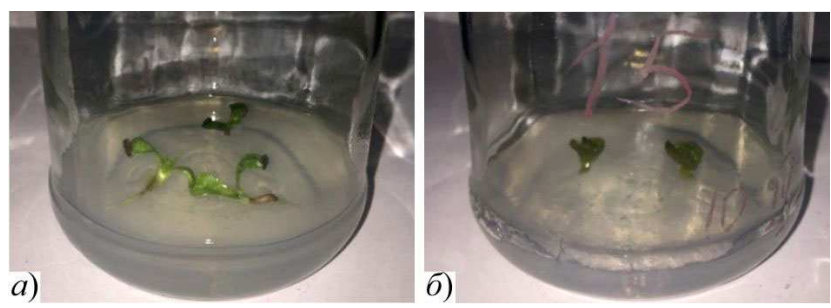

Рис. 1. Розвиток рослин-регенерантів із стерильних життєздатних експлантів (a) та стерильні нежиттєздатні експланти (б)

Також, за цієї самої концентрації добрі результати було зафіксовано при експозиції 20 хв і вихід стерильних життєздатних експлантів становив $87 \%$. Також встановлено, що зі зменшенням експозиції до 10 хв, як і в інших варіантах, на тканинах рослин залишалась інфекція і в подальшому експланти гинули.

Ефективним стерилізатором виявився $1,25 \%$ розчин септодор-форте, для якого за збільшення експозиції стерилізації від 15 до 20 хв отримано вихід стерильного матеріалу на рівні 83-90 \%. У подальшому, зі збільшенням концентрації до 2,5 \% при експозиції стерилізації від 15 до 20 хв вихід неінфікованих життєздатних есплантів становив від 81 до 84 \%. Однак, варто зазначити і те, що непоганий результат зафіксовано у стерилізатора хлорамін при концентрації 0,15 \% та експозиції стерилізації 15 хв, де вихід експлантів становив відповідно $83 \%$.

Некроз рослин-регенерантів (рис. 2) представляє собою відмерлі, як зазвичай сухі ділянки рослини, які різко відмежовані від здорової тканини. Найчастіше в них локалізовано збудник захворювання, який має округлу форму некротичних плям, що спричинено відмиранням клітин, що оточують місце ураження (Gamborg \& Eveleigh, 1968).

Експланти 3 прихованою інфекцією та фізіологічними порушеннями від токсичної дії стерилізатора, досліджено в усіх варіантах досліду, однак найбільшу кількість загиблих від некрозу рослин (див. рис. 2, $a$ та 2,б) виявлено для стерилізатора септодор-форте 3 концентрацією 0,5 \% (68-93 \%) при експозиції 10-20 хв.

За результатами проведених досліджень встановлено, що найефективнішим стерилізатором експлантів рослин калістефусу китайського $є 0,51 \%$ розчин гіпохлориду натрію при експозиції стерилізації 15 хвилин $98 \%$ стерильного матеріалу.

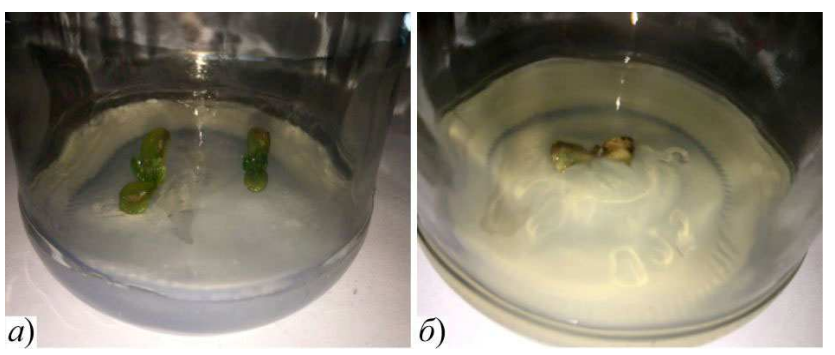

Рис. 2. Початок некрозу рослин-регенерантів $(a)$ та загиблі від некрозу рослини-регенеранти (б)

Стерилізатор септодор-форте $5 \%$ при експозиції стерилізації 20 хв забезпечив вихід стерильних живців на рівні $90 \%$, однак при цьому виявився некроз живців - $10 \%$. За згаданого вище стерилізатора при експозиції від 10 до 20 хв та різних концентраціях 1,25 та 2,5, відповідно, в хід неінфікованих життєздатних експлантів становив 83-84 \%, при некрозі - 6-8 \%.

Збільшення експозиції стерилізації більш як 20 хв забезпечувало вихід стерильного матеріалу до $100 \%$, однак рослини виявилися нежиттєздатними.

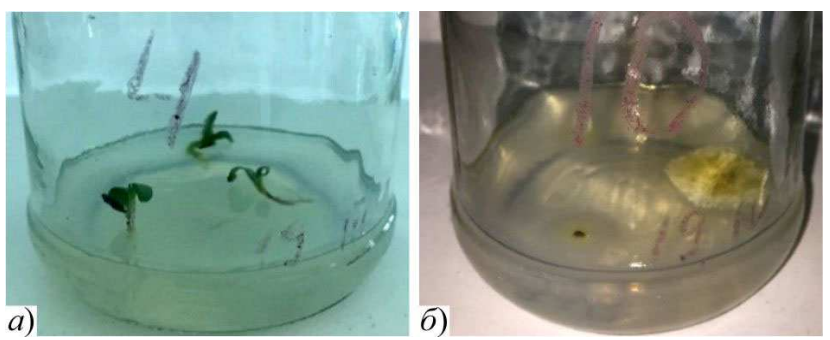

Рис. 3. Розвиток рослин-регенерантів із стерильних життєздатних експлантів $(a)$ та розвиток інфікованих рослин-регенерантів з експлантів - носіїв прихованої бактеріально-грибкової інфекції (б)

В усіх інших варіантах досліджень, поряд із незараженими інфекцією експлантів, виявлено рослини-регенеранти (рис. 3,a) у яких прихована бактеріально-грибкова інфекцією проявилась через 1,5-3,0 тижні після введення в культуру (рис. 3,б).

Висновки. У роботі наведено результати розмноження вихідних матеріалів калістефусу китайського 3 використанням біотехнологічної ланки. Визначено, що найефективнішим стерилізатором експлантів рослин калістефусу китайського $є 0,5 \%$ розчин гіпохлориду натрію при експозиції стерилізації 15 хв- $98 \%$ стерильного матеріалу. Рекомендуємо здійснювати введення в in vitro у період активної вегетації інтактних рослин (травень-липень), що вважають кращими строками введення експлантів калістефусу китайського. 


\section{Перелік використаних джерел}

Aleksandrova, M. S., \& Krestnikova, A. D. (1991). Ozelenenie balkonov. Moscow, 5 p. [In Russian].

Aleksieieva, N. M. (1999). Dlia tykh khto liubyt aistry. Kvity Ukrainy, 11, 2-3. [In Ukrainian].

Angiosperm Phylogeny Group III. (2009). An update of the Angiosperm Phylogeny Group classification for the orders and families of flowering plants: APG III. Bot. J. Linnean Society, 161, 105-121. London.

Antoniuk, N. M., \& Iashhenko, N. P. (2005). Deistvie khimicheskikh mutagenov $\mathrm{v}$ vodnykh rastvorakh i gazovoi faze na semena i kornevishha kann. Khimicheskie supermutageny $v$ selektcii, 336-343. Moscow: Science. [In Russian].

Bailey, L. H. (1950). The standart cyolopedia of Horticulture. London: Macmillan, $419 \mathrm{p}$.

Boreiko, A. M. (1989). Mutatcionnye protcessy i ikh znachenie dlia selektcii. Eksperimentalnyi mutagenez i ego ispolzovanie v selektcii. Kyiv: Publishing House AN SSSR, 17 p. [In Russian].

Boroevich, S., \& Fedorov, A. K. (Ed.). (1984). Printcipy i metody selektcii rastenii. Moscow: Kolos, 344 p. [In Russian].

Butenko, R. G. (1964). Kultury izolirovannykh tkanei i fiziologiia morfogeneza rastenii. Moscow: Science, 272 p. [In Russian].

Butenko, R. G. (1999). Biologiia kletok vysshikh rastenii in vitro $i$ biotekhnologii na ikh osnove. Moscow: FBK-Press, 160 p. [In Russian].

Gamborg, O. L., \& Eveleigh, D. E. (1968). Culture methods and detection of glucanases in suspension cultures of wheat and barley. Canadian journal of biochemistry, 46(5), 417-421.

Guliaev, G. V., \& Guzhov, Iu. L. (1972). Selektciia i semenovodstvo polevykh kultur. Moscow: Kolos, pp. 446-450. [In Russian].

Iaremenko, L. M., \& Lazitckaia, L. N. (1968). Odnoletnie tcvetochnye rasteniia. Kyiv: Urozhai, 136 p. [In Russian].
Kozhevnikov, V. I. (2000). Astra odnoletniaia. Stavropol: BiKmaster, 44 p. [In Russian].

Melnychuk, M. D., Novak, T. V., \& Kunakh, V. A. (2003). Biotekhnolohiia roslyn. Kyiv: PolihrafKonsaltynh, 520 p. [In Ukrainian].

Nechansky, Fr., \& Jirasek, V. (1967). Systematische Studie uber kultivierte Sommerastern (Gartenastern) - Callistephus chinensis Nees (Asteraceae). Pleslia., 39(2), 122-150.

Petrenko, N. A. (2001). Astry. Moscow: Armada-press, 32 p. [In Russian].

Shevel, L. O., \& Alekseeva, N. N. (2015). Osenizvezdnyi venok. Ogorodnik, 9, 30-32. [In Russian].

Shevel, L. O., \& Rudnyk-Ivashchenko, O. I. (2016). Dekoratyvni ta hospodarsko tsinni oznaky novykh sortiv kalistefusu kytaiskoho Callistephus chinensis (L.) Ness. Genetic resources of plants, 18, 97-106. [In Ukrainian].

Shhelokova, Z. I., Simonova, O. B., \& Belova, S. A. (1967). Selektciia i semenovodstvo, 6, 53-60. [In Russian].

Surhan, O. V., \& Melnyk, T. I. (2012). Reaktsiia sortiv Callistephus chinensis na meteorolohichni umovy periodu vehetatsii. (Ser. Agronomy and Biology). Bulletin of the Sumy National Agrarian University, 2(23), 21-27. [In Ukrainian].

Turchyna, S. Ya., Polishchuk, V. V., Balabak, A. F., \& Velychko, Yu. A. (2017). Analiz hospodarsko-biolohichnykh oznak introdukovanykh henotypiv rodu Callistephus chinensis (L.) Ness. z metoiu zaluchennia yikh v landshaftni kompozytsii. Ekolohichni aspekty introduktsii roslyn: Materials of the 6th International Scientific and Practical Conference "Plants and Urbanization", Dnieper, March 1-2, 2017, (pp. 103-105). [In Ukrainian].

Volkova, G. A. (1983). Odnoletnie astry v usloviiakh Komi ASSR. Leningrad: Science, 109 p. [In Russian].

V. V. Polishchuk, S. Ya. Turchina, M. Yu. Osipov Uman National University of Horticulture, Uman, Ukraine

\section{SELECTION OF STERILIZER FOR IN VITRO INTRODUCTION OF DONOR MATERIAL OF RESEARCH CALLISTEPHUS CHINENSIS (L.) NESS. VARIETIES FOR ITS FURTHER USE IN GREENING}

The analysis of literary sources indicates that within the explants and in the further development of them from the regeneration plants an infection can appear on both the surface and inside the plant. This significantly reduces the frequency of division of somatic or embryonic cells and other growth rates. At the same time, some microorganisms in certain stages of reproduction may remain inactive during several transplants of culture and only then begin to multiply. The purpose of our work was obtaining sterile non-infected plant material in the process of introducing into the culture and during the period of cultivation of plants, conducting of surface sterilization of the source plant material (seed) Callistephus Chinensis (L.) Nees., depending on the composition of the nutrient medium. Sterilization of the plant material was carried out with 5-15\% solution of chloramine, and $0.01-0.1 \%$ solution of sulam. We have chosen chloramine, sodium hypochloride and septodor-forte with different concentrations of the working solution as sterilizers. The number of genotypes that introduced was 100 seeds for all sterilizers. We have determined that the most effective sterilizer for Chinese explants of Callistephus is a $0.5 \%$ solution of sodium hypochlorite at a sterilization exposure of 15 minutes - $98 \%$ sterile material. It was found that an effective sterilizer was a $1.25 \%$ solution of septodor-forte, for which the output of sterile material at the level of $83-90 \%$ was obtained from 15 to 20 minutes, due to an increase in the exposure of sterilization. Subsequently, with an increase in concentration up to $2.5 \%$ at exposure of sterilization from 15 to 20 mines, the output of uninfected viable esptables ranged from 81 to $84 \%$. However, it should be noted that a good result was recorded in the sterilizer chloramine at a concentration of $0.15 \%$ and exposure of sterilization for 15 minutes, where the yield of explants was $83 \%$, respectively.

Keywords: nutrient medium; source material; Callistephus Chinensis; varieties; introduction; in vitro; economic and valuable features; genotype; vegetative material. 